\title{
STUDY OF THE ROLE OF SERUM CD163 AS A PROGNOSTIC TOOL IN MYCOSIS FUNGOIDES THERAPY
}

\author{
By
Tarek Salah El-Din Mohammed, Hussein Mohamed Hassab-El-Nabya, Mohammed Dardiri El-Hariria and Mohammed Said Ibrahim El- Shourbagy ${ }^{b}$ \\ Department of Dermatology, Venereology and Andrology a and Clinical Pathology \\ Department $^{\mathrm{b}}$, Faculty of Medicine, Al-Azhar University \\ *Corresponding author: Tarek Salah El-Din Mohammed \\ Mobile: (+20)01065626842, E-mail: $\underline{\text { dr_tarek_salah@yahoo.com }}$
}

\begin{abstract}
Background: Mycosis fungoides (MF) is the most common cutaneous $\mathrm{T}$ cell lymphomas (CTCL). Discrepancies between clinical and histopathological response to MF therapy led to search for more objectively tools to determine the presence of residual/recurrent skin involvement. Therefore, Cluster of Differentiation 163 (CD163) could be an interesting prognostic tool in evaluation of MF therapy.

Objective: To evaluate the relationship between serum CD163 level and staging of early MF and its prognostic value in treatment of early MF.

Patients and methods: This study was carried out at Dermatology Department, Al-Hussein University Hospital, Faculty of Medicine, Al-Azhar University, during the period from January 2016 to May 2018.

This study included 41 individuals (22 diagnosed as early MF and 19 healthy volunteers). Detection of sCD 163 by ELISA was done in MF patients twice. The first was done before starting treatment and the second was done 6 months after continuous therapy. Detection of SCD 163 of healthy volunteers was done.
\end{abstract}

Results: sCD 163 was significantly higher in MF patients than control group. It significantly reduced after treatment in MF patients, and it reduced significantly in patients received PUVA more than NB-UVB.

Conclusion: sCD 163 was elevated in MF patients and a useful follow up marker in early MF.

Keywords: Mycosis fungoides, Serum CD163, Cutaneous T cell lymphomas.

\section{INTRODUCTION}

MF is a malignant lymph proliferative disorder characterized by an infiltration of the skin with neoplastic skin homing $\mathrm{T}$ cells and represents approximately $50 \%$ of all CTCL cases (Yamashita et al., 2012). Early MF clinically and histologically resembles benign inflammatory skin diseases such as atopic dermatitis (AD), psoriasis, and chronic eczema which cause difficulty in diagnosis (Miyagaki and Sugaya, 2011). Investigations focusing on the use of immunohistochemistry testing as a tool to be more objectively determine the presence of residual/recurrent skin involvement by MF would be an interesting target in research field (Quaglino et al., 2011). The serum CD163 level had shown great diagnostic value because it was highly increased in many 
inflammatory diseases (Moller, 2012). The serum CD163 level was associated with the progression of CTCL (Makoto et al., 2012).

The aim of this study was to evaluate the relationship between serum CD163 level and staging of early MF and its prognostic value in treatment of early MF.

\section{PATIENTS AND METHODS}

This study was carried out at Dermatology Department, Al-Hussein University Hospital, Faculty of Medicine, Al-Azhar University. This study included twenty-two MF patients and nineteen healthy volunteers as control on a period from January 2016 to May 2018. Patients' age ranged from 11-76 years. There were 7 male patients and 15 females. Duration of MF in the studied group ranged from 0.5-7 years. An approval of the study was obtained from Al- Azhar University academic and ethical committee, and all participants provided written informed consents. Exclusion criteria for this study were patients had received treatment for $\mathrm{MF}$, history of chronic inflammatory skin diseases such as psoriasis or atopic dermatitis or history of chronic medical or immunological disorders that may affect serum CD 163 such as Gaucher's diseases, sepsis, bactermia and chest infection. Also, uncommitted patients were excluded. Staging of patients was based on TNMB classification system EORTC revision to the TNM classification of MF. All the patients received phototherapy (PUVA or NB-UVB) according to contraindications and tolerability of psoralin. Sessions were at least two per week for 6 months (at least 48 session / 6 months).

\section{Criteria of improvement (clinical improvement):}

Down staging, and improvement of itching (stage IA). Itching was considered as a parameter of improvement in this stage as itching is the most clue symptom, and patients with patches only (T1a/T2a) were distinguished from those with patches and plaques (T1b/T2b).

\section{Blood sampling:}

One blood sample from healthy volunteers was taken. Two blood samples were taken from all patients. First was taken before starting treatment and the second was taken 6 months after continuous therapy.

Detection of human CD163 by ELISA (Quantikine ${ }^{\circledR}$ ELISA, Human CD163 immunoassay kit; Catalog No\# DC1630; R\&D SYSTEMs Inc., a biotech ${ }^{\circledR}$ brand, USA and Canada).

\section{Statistical methods:}

Results were collected, tabulated, statistically analyzed by IBM personal computer and statistical package SPSS version 22 (Armonk, NY: IBM Corp, 2013). Quantitative data were expressed as mean \pm standard deviation (SD), range, median and the interquartile range (IQR). Qualitative data were expressed as frequency and percentage.

Chi-square test $(\chi 2)$ was used to study association between two qualitative variables. Mann-Whitney $U$ test (nonparametric test of significance) was used for comparison between two groups having quantitative variables not normally distributed. ANOVA test (test of significance) was used for comparison between more than two groups having 
quantitative variables. Kruskall-Walklis test (nonparametric test of significance) was used for comparison between more than two groups having quantitative variables not normally distributed. Wilcoxon signed ranks test (nonparametric test of significance) was used as a test of significance used for comparison of two means that were from the same group at two different times when the data were not normally distributed. Spearman's correlation (rho) coefficient measured how variables or rank orders are related. P-value of $<0.05$ was considered statistically significant.

\section{RESULTS}

Patients with MF comprised 31.8\% men and $68.2 \%$ women. Patients' age ranged from 11-76 years with a mean $37.64 \pm 16.89$ years. Regarding demographic data the patients and control groups were matched as regards their age and sex (Table 1).

Table. (1): Demographics of the patients with MF and control group

\begin{tabular}{|l|c|c|c|c|}
\hline Groups & $\begin{array}{c}\text { MF Patients } \\
(\mathrm{n}=22)\end{array}$ & $\begin{array}{c}\text { Control } \\
\text { group } \\
(\mathrm{n}=19)\end{array}$ & $\begin{array}{c}\text { Test of } \\
\text { significance }\end{array}$ & P-value \\
\hline $\begin{array}{l}\text { Age (years) } \\
\text { Mean } \pm \text { SD }\end{array}$ & $\begin{array}{c}37.64 \pm 16.89 \\
\begin{array}{l}39.5 \& 24 \\
\text { Median \& IQR }\end{array}\end{array}$ & $\begin{array}{c}36 \pm 9.05 \\
37 \& 8 \\
\text { range }\end{array}$ & $\begin{array}{c}\text { Mann- } \\
\text { Whitney=0.562 }\end{array}$ & 0.575 \\
\hline $\begin{array}{l}\text { Sex [No (\%)]: } \\
\text { Males }\end{array}$ & $7(31.8 \%)$ & $\begin{array}{c}11(57.9 \%) \\
8(42.1 \%)\end{array}$ & $\chi^{2}=2.81$ & 0.093 \\
Females & $15(68.2 \%)$ & & \\
\hline
\end{tabular}

Before starting treatment, sCD163 was significantly higher in MF patients than control group. In MF patients, mean serum CD 163 level was $44.73 \pm 26.65$ in contrast to $27.2 \pm 5.6$ in control group (Table 2).

Table (2): Serum CD163 levels in MF patients and control group (before treatment)

\begin{tabular}{|c|c|c|c|c|}
\hline $\begin{array}{ll}\text { Items } & \text { Groups }\end{array}$ & $\begin{array}{c}\text { MF Patients } \\
(\mathrm{n}=22)\end{array}$ & $\begin{array}{c}\text { Control group } \\
(\mathrm{n}=19)\end{array}$ & $\begin{array}{c}\text { Test of } \\
\text { significance }\end{array}$ & $\begin{array}{c}\text { P- } \\
\text { value }\end{array}$ \\
\hline $\begin{array}{l}\text { CD163 levels } \\
\text { Mean } \pm \text { SD } \\
\text { Median \& IQR } \\
\text { range }\end{array}$ & $\begin{array}{c}44.73 \pm 26.65 \\
46 \& 27.25 \\
8-100\end{array}$ & $\begin{array}{c}27.2 \pm 5.6 \\
29 \& 8 \\
15-36\end{array}$ & $\begin{array}{c}\text { Mann- } \\
\text { Whitney=2.82 }\end{array}$ & 0.0048 \\
\hline
\end{tabular}

Duration of MF in the studied group ranged from $0.5-7$ years with a mean 2.21 years \pm 1.85 . Regarding to demographic characteristics of MF patients there was no significant correlation between ages, sex, disease duration and serum levels of CD163 in MF (Table 3). 
Table (3): Serum CD163 levels before treatment in relation to demographic characteristics in MF patients

\begin{tabular}{|l|c|c|c|}
\hline \multicolumn{1}{|c|}{ Items } & $\begin{array}{c}\text { Serum } \\
\text { CD163 levels } \\
\text { in MF } \\
\text { patients } \\
\text { characteristics }\end{array}$ & $\begin{array}{c}\text { Test of } \\
\text { significance }\end{array}$ & P-value \\
\hline Age (years) & \multicolumn{2}{|c|}{ rho=0.12 } & 0.611 \\
\hline Duration of MF (years): & \multicolumn{2}{|c|}{ rho=0.39 } & 0.07 \\
\hline Sex: & \multicolumn{2}{|c|}{} & \\
Males (n=7) & $53.43 \pm 21.90$ & & \\
Mean \pm SD & $50 \& 36$ & Mann- & 0.162 \\
Median \& IQR & & Whitney=1.45 & \\
Females (n=15) & $40.67 \pm 28.36$ & & \\
Mean \pm SD & $36 \& 34$ & & \\
Median \& IQR & & & \\
\hline
\end{tabular}

Rho: Spearman's correlation coefficient.

Seventeen patients had classic MF lesions, 3 patients had hypopigmented type and 2 patients had mixed lesions (one case was classic and follicular lesions and the other case was classic and hypopigmented) representing $77.3 \%$, $13.6 \%$ and $9.1 \%$ respectively. 20 patients were complaining of itching during presentation. Regarding to MF stage, stage IB was the predominant stage as stage IB cases was 16 representing $72.7 \%$, while 4 patients at stage IIA and 2 patients at stage IA representing $18.2 \%$ and $9.1 \%$ respectively. There was no significant correlation between clinical characteristics of MF patients (stage of MF, type of lesion or itching) and their serum CD163 level (Table 4).

Table (4): Serum CD163 levels and clinical characteristics in MF patients

\begin{tabular}{|l|c|c|c|}
\hline $\begin{array}{l}\text { Clinical Item } \\
\text { characteristics }\end{array}$ & $\begin{array}{c}(\mathrm{n}=22) \\
\text { Mean } \pm \text { SD }\end{array}$ & $\begin{array}{c}\text { Test of } \\
\text { significance }\end{array}$ & P-value \\
\hline Stage of MF: & $22.50 \pm 13.44$ & Kruskall & \\
IA ( $\mathrm{n}=2)$ & $50.19 \pm 27.38$ & Wallis=2.65 & 0.266 \\
IB (n=16) & $34.00 \pm 26.65$ & & \\
IIA (n=4) & $50.12 \pm 26.67$ & Kruskall & \\
\hline Type of lesion: & $19.00 \pm 4.24$ & Wallis=3.63 & 0.163 \\
Classic (n=17) & $31.33 \pm 24.03$ & & \\
Hypopigmented (n=3) & & Mann- & \multirow{2}{*}{0.423} \\
Mixed (n=2) & $45.90 \pm 27.50$ & Whitney=0.80 & \\
\hline Itching: & $33.00 \pm 15.56$ & & \\
Present $(n=20)$ & Absent (n=2) &
\end{tabular}

6 patients were treated with NB-UVB and the other 16 patients were treated with PUVA representing $27.3 \%$ and $72.7 \%$ respectively. The mean number of treatment sessions was 56.04 sessions +9.68. After treatment, 17 patients showed clinically improvement however there 5 patients were none improved. Serum CD 
163 significantly reduced after treatment in MF patients as the mean CD 163 level was $44.73 \pm 26.65$ before treatment to $24.95 \pm 12.94$ after treatment (Table 5). This difference was created by significant difference in mean of the serum CD163 level before and after treatment in patients received PUVA while using NB-UVB showed non-significant difference (Table 5). However, there was no significant relation between reduction in serum CD163 and number of sessions (Table 5).

Table (5): Serum CD163 level before and after treatment in MF patients $(n=22)$

\begin{tabular}{|c|c|c|c|c|}
\hline \multirow{2}{*}{ Items } & \multicolumn{2}{|c|}{ MF patients $(n=22)$} & \multirow{2}{*}{ Test of significant } & \multirow{2}{*}{$\begin{array}{c}P \text { - } \\
\text { value }\end{array}$} \\
\hline & Before TTT & After TTT & & \\
\hline $\begin{array}{l}\text { CD163 levels (ng/ml) } \\
\text { Mean } \pm \text { SD } \\
\text { Median } \\
\text { range }\end{array}$ & $\begin{array}{l}44.73 \pm 26.65 \\
44.5 \\
8-100\end{array}$ & $\begin{array}{l}24.95 \pm 12.94 \\
25.5 \\
8-48\end{array}$ & $\begin{array}{c}\text { Wilcoxon signed ranks } \\
\text { test: } \\
2.97\end{array}$ & 0.003 \\
\hline $\begin{array}{l}\text { NB-UVB } \\
\text { PUVA }\end{array}$ & $\begin{array}{l}33.57 \pm 16.73 \\
49.93 \pm 29.22\end{array}$ & $\begin{array}{l}27.00 \pm 13.37 \\
24.00 \pm 13.09\end{array}$ & $\begin{array}{c}\text { Wilcoxon signed ranks } \\
\text { test: } \\
0.17 \\
3.85\end{array}$ & $\begin{array}{l}0.502 \\
0.002\end{array}$ \\
\hline Number of sessions & & rho $=-0$ & & 0.082 \\
\hline
\end{tabular}

Results showed non-significant treatment and the mean levels of CD163 differences between the outcome of before treatment in MF patients (Table 6).

Table.(6): Mean CD163 levels before and after treatment in relation to outcome of treatment in MF patients (prognostic significance)

\begin{tabular}{|l|c|c|c|c|}
\hline MF patients & $\begin{array}{c}\text { Improved } \\
(\mathrm{n}=17) \\
\text { Mean } \pm \text { SD }\end{array}$ & $\begin{array}{c}\text { Non-improved } \\
(\mathrm{n}=5) \\
\text { Mean } \pm \text { SD }\end{array}$ & $\begin{array}{c}\text { Mann- } \\
\text { Whitney } \\
\text { test }\end{array}$ & P-value \\
\hline CD163 levels (ng/ml): & & & & \\
Before treatment & $46.53 \pm 23.98$ & $38.60 \pm 36.98$ & 0.58 & 0.571 \\
After treatment & $21.35 \pm 9.56$ & $37.20 \pm 16.45$ & 2.76 & 0.012 \\
\hline
\end{tabular}

Regarding to clinical characteristics of the MF patients, serum CD163 significantly reduced in patients with stage IB, classic lesions and patients presented with itching in relation to other clinical characteristics. There was no significant relation between reduction in CD163 and disease duration (Table 7). 
Table (7): Serum CD163 levels before and after treatment in relation to clinical characteristics of the MF patients $(n=22)$

\begin{tabular}{|l|c|c|c|c|}
\hline $\begin{array}{r}\text { Serum CD 163 } \\
\text { levels in } \\
\text { MFpatients }\end{array}$ & $\begin{array}{c}\text { Before TTT } \\
\text { Mean } \pm \text { SD }\end{array}$ & $\begin{array}{c}\text { After TTT } \\
\text { Mean } \pm \text { SD }\end{array}$ & $\begin{array}{c}\text { Wilcoxon } \\
\text { signed } \\
\text { ranks test }\end{array}$ & P-value \\
Items & & & 1.00 & 0.500 \\
Stage of MF: & $22.50 \pm 13.44$ & $21.50 \pm 12.02$ & 3.29 & 0.005 \\
Stage IA & $50.19 \pm 27.38$ & $26.25 \pm 14.21$ & 1.42 & 0.252 \\
Stage IB & $34.00 \pm 26.65$ & $21.50 \pm 9.04$ & & \\
Stage IIA & $50.12 \pm 26.67$ & $26.59 \pm 13.85$ & 3.40 & 0.004 \\
\hline Type of lesion: & $19.00 \pm 4.24$ & $21.00 \pm 8.49$ & 0.67 & 0.626 \\
Classic & $31.33 \pm 24.03$ & $18.33 \pm 9.08$ & 1.40 & 0.297 \\
Hypopigmented & & & & \\
Others & $45.90 \pm 27.50$ & $25.65 \pm 13.07$ & 3.33 & 0.003 \\
\hline Itching: & $33.00 \pm 15.56$ & $18.00 \pm 12.73$ & 0.75 & 0.590 \\
Present & \multicolumn{3}{|c|}{ Rho =-0.018 } \\
Absent & \multicolumn{3}{|l}{0.937} \\
\hline Duration of MF & &
\end{tabular}

\section{DISCUSSION}

CD163 is a macrophage specific protein. It has been proven to be expressed on tumor associated macrophages and associated with poor prognosis. sCD163 has emerged as a useful biomarker of macrophage activation in various diseases (Moller, 2012 and Etzerodt \& Moestrup, 2013).

In this study, we investigated the possible relation between soluble CD163 and early MF stages as a tool for disease improvement during treatment. sCD163 levels were significantly higher in $\mathrm{MF}$ patients than those in control group. This agreed with Sugaya et al. (2012) and Wu et al. (2014), who reported similar results. Sugaya et al. (2012) proved increased CD 163 in MF patients through both immunohistochemistry and ELISA. This increase was associated with disease progression. On the other hand, Wu et al. (2014) demonstrated increased mRNA expression of CD163 in MF lesions (patches and plaques) but not in normal skin.

The first experimental evidence suggested the role of TAMs in animal cutaneous lymphoma model very similar to human cutaneous lymphoma (Wu et al., 2011). Thereafter, multiple studies emphasized the crucial role of TAMs in cutaneous lymphoma (Sugaya et al., 2012, Furudate et al., 2015, Furudate et al., 2016 and Kara et al., 2017).

In our study, there was no significant relation between demographic or clinical data of MF patients and sCD163. Unexpectedly, there was no relation between MF stages and sCD163 which may be due to limitation in our study to early stage of the disease. This was consistent with Sugaya et al. (2012) who found increased serum CD163 in advanced stages, which is not reach the significant value.

Multiple previous studies showed positive relation between MF stage and 
tissue CD163. Wu et al. (2014) reported increased mRNA expression of CD163 in thick plaques versus thinner patches. Furudate et al. (2015) found positive relation between MF stage and number of CD163 positive cells.

This conflict between our result and the previous results as regard the correlation between CD163 and MF stages has many explanation:

- The unequal distribution of cases in the different groups in this study.

- It may reflect a minor role of TAMs and CD163 in early stages MF.

- The different methodology in each research (mRNA expression, immunohistochemistry and serum sCD163). Is sCD163 able to express the accurate activity of TAMs, this question should be addressed.

The most striking result was the significant reduction of sCD163 after treatment. This reduction was significant in classical type, stage IB, patients presented with itching and improved cases. In addition, this reduction was significant in patients received PUVA therapy versus NB-UVB. This finding may help us to consider sCD163 as a useful follow up marker especially in early MF stages.

The significant reduction in SCD163 in improved patients only, refers to a major role of TAMs as a target for therapy in early stages of MF. In addition, this may reflect the mode of action exerted by phototherapy in treatment of cutaneous lymphoma. In fact, the role of TAMs as a target for cutaneous lymphoma treatment was focused by many authors during the last few years.
Furudate et al. (2016) investigated the effect of IFN therapy on TAMs in MF patients. They supposed that TAMs is a major target of INF therapy in MF.

Sugaya et al. (2012) found significant reduction in the number of CD163 +ve cells after treatment (in three MF patients only). This was even confirmed experimentally by $\mathrm{Wu}$ et al. (2014) who reported reduction in tumor growth of human xenograft model of cutaneous lymphoma after TAMs depletion. We can state that TAMs inhibition will alter disease progression in cutaneous lymphoms.

The sCD163 showed no prognostic capabilities as there was no significant difference between sCD163 levels before treatment in improved and non-improved patients. In of the work Sugaya et al. (2012) patients with increased number of CD136 positive cells had poor prognosis (depending on survival for 100 months) in comparison to the patients with small numbers. Clearly these are two different methods to evaluate prognosis.

Patients received PUVA showed significant reduction of sCD163. We believe this may be related to PUVA mechanism of action but not efficacy of treatment as most of the non-improved patients were receiving PUVA therapy (4 out of 5).

The main limitation of this study is the small number of cases and the unequal distribution of cases in different groups, what makes the statistical analysis in some occasions inaccurate. 


\section{CONCLUSION}

The sCD163 is elevated in MF patients. The sCD163 is a useful follow up marker in early MF. These results suggest that CD163 may have important role in the development of CTCL. Further studies are needed to elucidate the precise role of sCD163 in early and advanced stages of MF. Further studies are recommended to investigate the role of sCD163 in resistant types of MF.

\section{REFERENCES}

1. Etzerodt A. and Moestrup S. (2013): CD163 and Inflammation: Biological, Diagnostic, and Therapeutic Aspects. Antioxidants \& redox signaling, 18:2352-2363.

2. Furudate S., Fujimura T., Kakizaki A., Hidaka T., Asano M. and Aiba S. (2016): Tumor-associated M2 macrophages in mycosis fungoides acquire immunomodulatory function by interferon alpha and interferon gamma. $\mathrm{J}$ of Dermatol Science, 83:182-189.

3. Furudate S., Fujumira T., Kakizaki A., Kambayashi Y., Asano M., Watabe A. and Aiba S. (2015): The possible interaction between periostin expressed by cancer stroma and tumor-associated macrophages in developing mycosis fungoides. ExpDermatol, 25:107-112.

4. Kara D., Ozsarac K., Uzar M., Bozdogan O. and Gunduz O. (2017): The role of macrophages in the pathogenesis of mycosis fungoides. Clin and ExpDermatol, 42:496-502.

5. Makoto S., Tomomitsu M., Hanako O., Hiraku S., Hiromichi K., Masahiro K., Hideki F., Yoshihide A., Yayoi T., Takafumi K., Hitoshi O. and Shinichi S. (2012): Association of the numbers of CD163+ cells in lesional skin and serum levels of soluble
CD163 with disease progression of cutaneous $\mathrm{T}$ cell lymphoma.Journal of Dermatological Science, 68:45-51.

6. Miyagaki T. and Sugaya M. (2011): Erythrodermic CTCL: how to differentiate this rare disease from atopic dermatitis. J Dermatol Sci, 64:1-6.

7. Moller H. (2012): Soluble CD163. Scand J Clin Lab Invest, 72:1-13.

8. Quaglino P., Pimpnelli N. and Berti E. (2012): Time course, clinical pathways, and long-term hazards risk trends of disease progression in patients with classic mycosis fungoides: a multicenter, retrospective followup study from the Italian Group of Cutaneous Lymphomas. Cancer, 118 (23): 5830-5839.

9. Sugaya M., Miyagaki T., Ohmatsu H., Suga H., Kai H., Kamata M., Fujita H., Asano Y., Tada Y., Kadono T., Okochi H. and Sato S. (2012): Association of the numbers of CD163+ cells in lesional skin and serum levels of soluble CD163 with disease progression of cutaneous $\mathrm{T}$ cell lymphoma. Journal of Dermatological Science, 68:45-51.

10. Wu X., Schulte B., Zhou Y., Haribhai D., Mackinnon A., Plaza J., Williams C. and Hwang S. (2014): Depletion of M2-like tumorassociated macrophages delays cutaneous $\mathrm{T}$ cell lymphoma development in vivo.J Invest Dermatol, 134:2814-2822.

11. Wu X., Sells R. and Hwang S. (2011): Upregulation of inflammatory cytokines and oncogenic signal pathways preceding tumor formation in a murine model of $\mathrm{T}$-cell lymphoma in skin. J Invest Dermatol, 131:1727-1734.

12. Yamashita T., Abbade L., Marques M. and Marques S. (2012): Mycosis fungoides and Sézary syndrome: clinical, histopathological and immunohistochemical review and update. An Bras Dermatol, 87:817-830. 
در اسة دور معامل التمبز 163 كمؤشر فى تقييم علاج مرض الفض الفطار الفطر انى

طارق صلاح الدين محمد، حسين محمد حسب النبى1، محمد درديرى الحريزي1، محمد

$$
\text { سعيد ابراهيم الثوربجى } 2
$$

قسمي الأمراض الجلاية والتناسلية1، و الباتولوجيا الاكلينيكية2

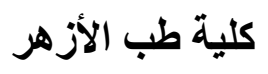

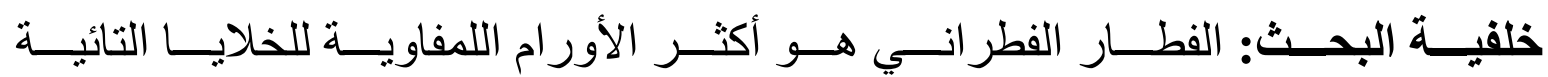

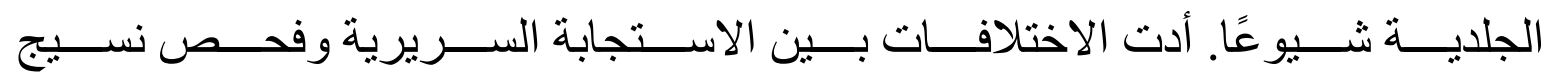

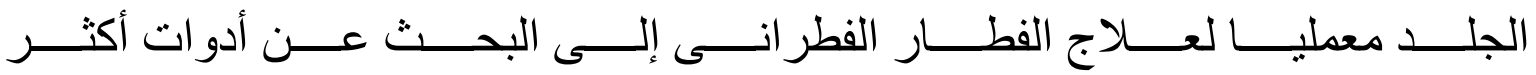

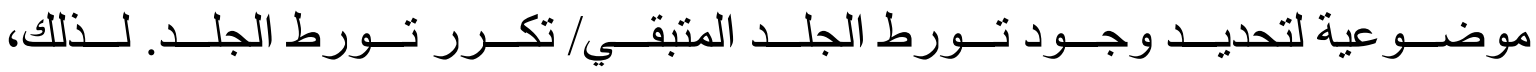

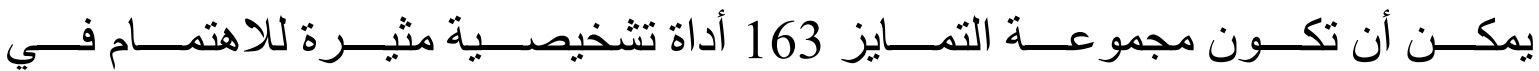
تقييم علاج الفطار الفطر انى.

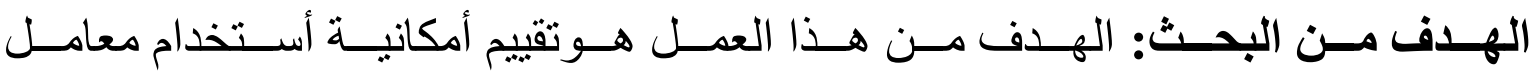

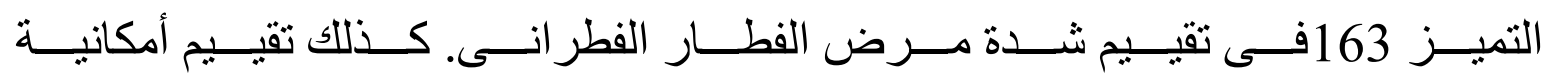

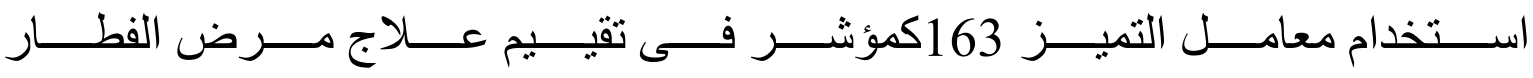
الفطر انى.

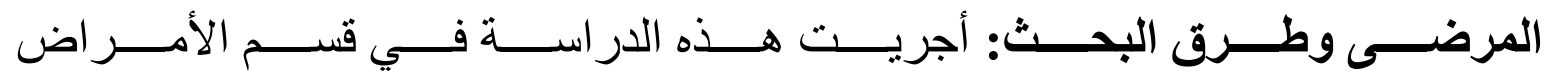

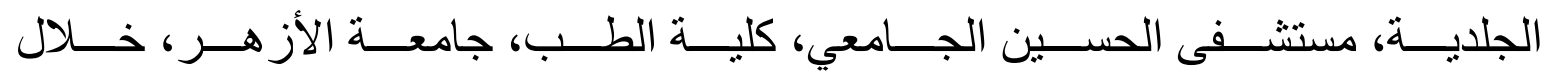

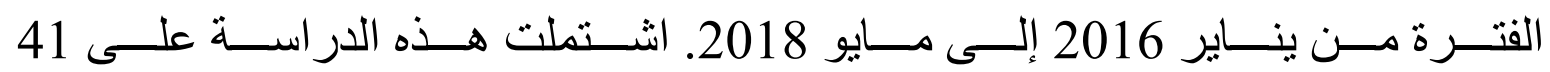

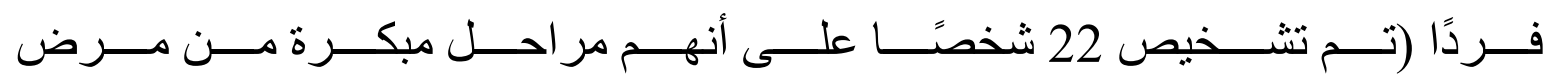

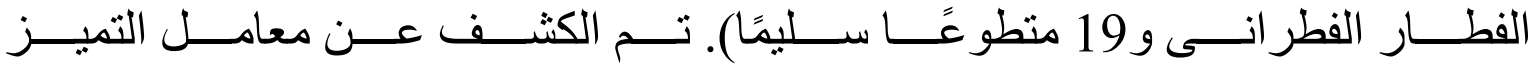

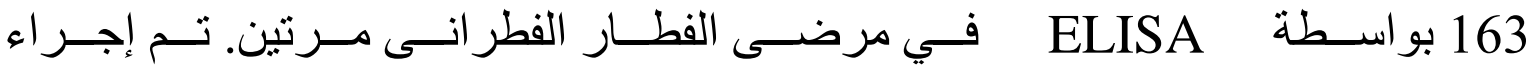

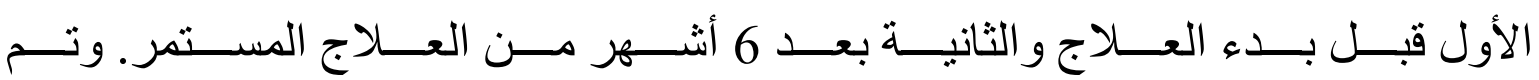
الكثف عن 163 sCD من المتطو عين الأصحاء. 


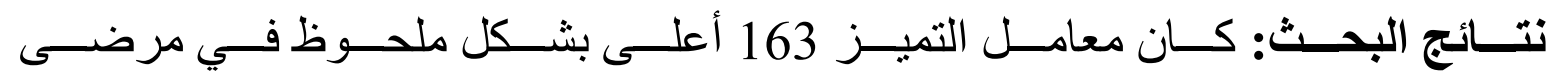

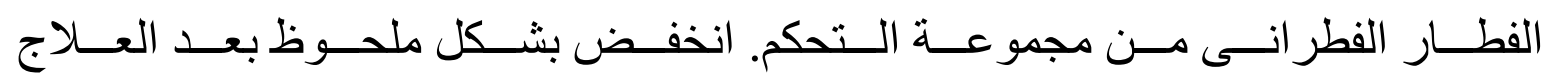

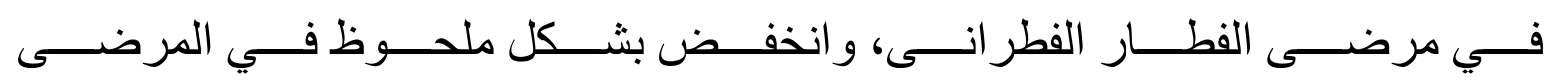
الذين تلقو ا بوفا أكثر من الين تلقو ا الأشعة فوق بنفسجية ضيقة وانئة النطاق.

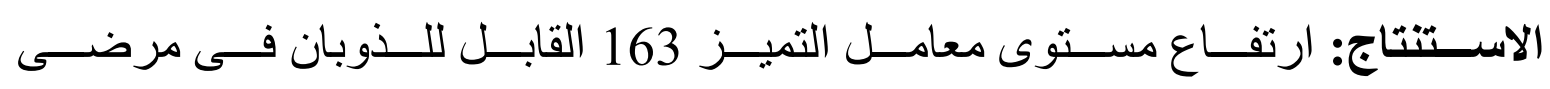

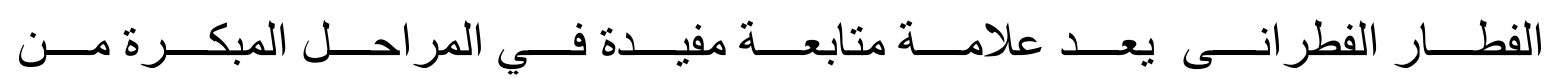
مرض الفطار الفطر انى. - مرك. 